\title{
DAMPAK KEBIJAKAN TARIF DAN NON-TARIF TERHADAP PERMINTAAN DAN DAYA SAING TUNA INDONESIA DI PASAR UNI EROPA, AMERIKA DAN JEPANG
}

\section{The Impact of Tariff and Non-Tariff Policy on Demand and Competitiveness of Tuna Commodity in European Union, United States of America and Japan Market}

\author{
Ratih Wijayanti, Irham, Suhatmini Hardyastuti \\ Pascasarjana Ekonomi Pertanian, Fakultas Pertanian Universitas Gadjah Mada
}

\begin{abstract}
The objective of this study is to analyse the impact of implementation tariff and non-tariff policy also the other factors on demand and competitiveness Indonesia's tuna commodity. Panel data was implemented in this research because beside used amually time series data during the period 1983-2008 also used cross section data which describe the demand and competitiveness condition of Indonesia's tuna commodity in three major market. Equation models in this research were estimated with Generalized Least Square (GLS) method with fixed effect to analyse all of demand and competitiveness of export tuna in ihree major market and Ordinany Least Square (OLS) method to analyse demand and competitiveness of expon tuna in each market. Meanwhile the comperitiveness of tuna is measured using Revealed Comparatif Advantage (RCA) index. The results show that export price in European union and shrimp price in Japan are main factors the demand of Indonesia's tuna export in three major market. The change of Gross Domestic Product (GDP) Japan has not been influenced the demand of Indonesia's tuna export to these country because Japan's import of fishery product from Indonesia has been done frequently and Indonesia's market share is very high. Export tuna from Indonesia is competing with export tuna from Thailand in European and Japan market while with export tuna from Philippines in USA market. Tariff policy more reduce and didn't influenced on demand and competitiveness. This finding were confirmed by significancy which more little than non-tariff policy.
\end{abstract}

Keywords: tariff and non-tariff policy, export of tuma, competitiveness

\section{INTISARI}

Penelitian ini bertujuan untuk mengetahui dampak penerapan kebijakan tarif dan non-tarif serta beberapa faktor lainnya terhadap permintaan dan daya saing tuna Indonesia. Data dalam penelitian ini dianalisis menggunakan data panel karena selain menggunakan data runtut waktu (1983-2008) juga menggunakan data silang yang menggambarkan kondisi permintaan dan daya saing tuna di ketiga pasar yaitu Uni Eropa, Amerika dan Jepang. Model persamaan dalam penclitian ini diestimasi dengan metode data panel (Generalized Least Square/ GLS dengan efek tetap) untuk menggambarkan seluruh permintaan dan daya saing ekspor tuna ke tiga pasar dan metode Ordinary Least Square (OLS) untuk menggambarkan kondisi permintaan dan daya saing tuna di masing-masing pasar. Pengukuran daya saing tuna dengan menggunakan indeks Revealed Comparatif Advantage (RCA). Hasil analisis menunjukkan bahwa harga ekspor di Uni Eropa dan harga udang di Jepang merupakan penentu utama permintaan tuna Indonesia di pasar produktif. Impor perikanan Jepang akan produk tuna dari Indonesia yang sudah rutin dilakukan dan besarnya pangsa pasar tuna Indonesia di Jepang menyebabkan perubahan pendapatan nasional (GDP masyarakat Jepang) tidak mempengaruhi permintaan tuna Indonesia ke negara tersebut. Indonesia bersaing dengan Thailand di pasar Uni Eropa dan Jepang serta bersaing dengan Filipina di pasar Amerika. Kebijakan tarif semakin tidak berpengaruh terhadap permintaan dan daya saing tuna Indonesia ke pasar produktif yang dibuktikan dengan nilai signifikansi yang lebih kecil dibandingkan kebijakan non-tarif yang diberlakukan.

Kata kunci: kebijakan tarif dan non-tarif, ekspor tuna, daya saing

\section{PENDAHULUAN}

Indonesia secara potensial memiliki sumberdaya alam perikanan yang sangat besar karena sebagian besar wilayahnya adalah lautan dengan luas perairan laut yang temasuk dalam Zona Ekonomi Eksklusif (ZEE) mencapai 5,8 juta $\mathrm{km}^{2}$. Namun sumbangan subsektor perikanan terhadap Produk Domestik Bruto (PDB) sekto: pertanian hanya sebesar $16,31 \%$ dengan pangsa ekspor terhadap nilai ekspor nonmigas hanya sebesar $7,09 \%$. Hal ini dikarenakan oleh beberapa hal antara lain sumberdaya perikanan baru dimanfaatkan sekitar $39,82 \%$, panjang pantai $95.181 \mathrm{~km}$ dengan potensi tambak 1,2 juta ha dan perairan umum sebesar 2,8 juta ha baru dimanfaatkan sekitar 50\% (DKP, 2009). 
Berdasarkan kondisi wilayah tersebut, Indonesia memiliki peluang untuk memposisikan diri sebagai salah satu produsen dan eksportir produk perikanan. Menurut Dahuri (2002) cit., Koeswoyo (2006) hal ini terlihat dari meningkatnya permintaan produk perikanan terutama udang, tuna dan rumput laut baik di pasar domestik maupun pasar internasional, sebagai akibat bergesernya selera konsumen dari red meat ke white meat setelah merebaknya berbagai penyakit ternak seperti penyakit mulut dan kuku.

Sementara itu, Food Agriculture Organization (FAO) memprediksikan bahwa hingga tahun 2015 masih terjadi kekurangan suplai ikan dunia sebesar dua juta ton per tahun akibat dari permintaan ikan dunia yang cenderung terus meningkat setiap tahunnya baik untuk konsumsi maupun bahan baku agroindustri. Dengan demikian pengembangan tuna sebagai salah satu produk perikanan, memiliki peran penting dalam upaya meningkatkan penerimaan devisa negara dan kegiatan ekonomi dalam negeri. Pasar tujuan ekspor tuna Indonesia beberapa tahun ini masih didominasi oleh pasar produktif yaitu ke Jepang, Amerika Serikat dan Uni Eropa sebagaimana ditunjukkan dalam Tabel 1.

Namun demikian peluang tersebut belum dapat dimanfaatkan secara maksimal karena perdagangan internasional produk perikanan Indonesia dan negara berkembang lainnya dihadapkan pada berbagai masalah pemasaran khususnya hambatan tarif dan non- tarif yang berdampak pada tingginya harga ekspor produk perikanan di negara pengimpor. Saat ini tarif untuk produk perikanan di negara-negara maju yang menjadi tujuan utama ekspor Indonesia dinilai masih terlalu tinggi. Sebagai contoh Uni Eropa memberlakukan tarif yang sangat tinggi yaitu $24 \%$ untuk tuna kaleng dan $16 \%$ untuk tuna segar (Ditjen PPHP, 2006). Walaupun dalam Konferensi Tingkat Menengah (KTM) III WTO tahun 2001 di Doha telah disepakati bahwa semua hambatan tarif akan segera dievaluasi dan diturunkan secara bertahap namun dalam merealisasikannya masih terus dihambat oleh negara-negara maju.

Selain tarif, hambatan non tarif juga menjadi kendala bagi ekspor produk perikanan Indonesia. Sehubungan dengan meningkatnya pengetahuan dan kepedulian konsumen tentang keamanan dan mutu makanan yang dikonsumsi, sejumlah negara importir cenderung memperketat persyaratan tentang keamanan pangan yang dapat berakibat pada naiknya biaya tambahan ekspor (Ahmed, 2006). Kebijakan non tarif dari negara-negara terscbut telah menjadi hambatan bagi negara-negara eksportir baik yang bersifat teknis (labelling dan packaging) maupun non teknis terutama aspek sanitasi dan fitosanitasi (Sanitary and Phytosanitary/ SPS). Kedua hambatan ini sering dipakai oleh negara-negara maju, karena hambatan jenis ini berhubungan erat dengan penguasaan teknologi dan tingginya standar hidup. Bahkan akhir-akhir ini negara maju juga telah menggunakan isu kelestarian lingkungan sebagai persyaratan baru dalam importasi produk perikanan.

Tabel 1. Perkembangan Volume dan Nilai Ekspor Tuna Indonesia di Negara Tujuan 2006-2008

\begin{tabular}{|c|c|c|c|c|c|c|c|c|}
\hline \multirow{2}{*}{ Negara Tujuan } & \multicolumn{3}{|c|}{ Volume (Ton) } & \multicolumn{3}{|c|}{ Nilai (000 US\$) } & \multicolumn{2}{|c|}{$\begin{array}{c}\text { Persentase } \\
\text { terhadap Total } \\
\text { (Tahun 2008) }\end{array}$} \\
\hline & 2006 & 2007 & 2008 & 2006 & 2007 & 2008 & $\begin{array}{c}\text { Volume } \\
(\%)\end{array}$ & $\begin{array}{l}\text { Nilai } \\
(\%)\end{array}$ \\
\hline Jepang & 21.657 & 31.330 & 26.710 & 76.250 & 112.668 & 115.740 & 20,54 & 33,34 \\
\hline Amerika Serikat & 4.182 & 21.375 & 18.370 & 14.946 & 73.565 & 70.804 & 14,12 & 20,39 \\
\hline Uni Eropa & 2.416 & 12.610 & 12.345 & 7.151 & 25.800 & 34.293 & 9,49 & 9,88 \\
\hline Saudi Arabia & 2.897 & 3.576 & 4.490 & 10.156 & 12.976 & 19.561 & 3,45 & 5,63 \\
\hline Singapura & 2.909 & 3.140 & 1.926 & 7.573 & 5.977 & 4.740 & 1,48 & 1,37 \\
\hline Lainnya & 63.567 & 56.001 & 74.151 & 152.220 & 92.315 & 129.995 & 57,01 & 37,44 \\
\hline Total & 91.822 & 121.316 & 130.056 & 250.567 & 304.348 & 347.189 & 100,00 & 100,00 \\
\hline
\end{tabular}

Sumber: Kelautan dan Perikanan dalam Angka, 2009 
Selain hambatan perdagangan tersebut, komoditas ekspor perikanan lainnya terutama udang diperkirakan juga berpengaruh terhadap permintaan tuna Indonesia. Potensi negara pengimpor yang tercermin dari Gross Domestic Product (GDP), jumlah penduduk dan nilai tukar rupiah terhadap mata uang negara pengimpor diperkirakan juga berpengaruh terhadap permintaan tuna Indonesia. Sementara itu keberadaan negaranegara kompetitor seperti Thailand dan Filipina selama ini juga menjadi ancaman bagi daya saing ekspor tuna Indonesia. Bcrdasarkan kondisi tersebut maka dilakukan penclitian untuk mengetahui bagaimana dampak penerapan kebijakan tarif dan non-tarif di ketiga pasar produktif (Uni Eropa, Amerika dan Jepang) serta beberapa variabel pendukung lainnya terhadap permintaan dan daya saing tuna Indonesia di pasar tujuan utama ekspor perikanan dunia yaitu Uni Eropa, Amerika dan Jcpang.

\section{METODE PENELITIAN}

Pelaksanaan penelitian ini dilakukan dengan metode deskriptif analitis. Jenis data yang digunakan dalam penelitian ini adalah data sekunder yang terdiri dari data kuantitatif dan kualitatif. Data yang diperolch merupakan data runut waktu (time series) selama kurang lebih dua puluh enam tahun yaitu 1983-2008 yang diolah secara panel. Data kuntitatif yang digunakan berupa ekspor tuna Indonesia ke Uni Eropa, Amerika dan Jepang dalam volume (ton) dan nilai (US\$), produksi tuna (ton), harga domestik tuna, harga negara pesaing ekspor tuna Indonesia (Thailand dan Filipina), harga udang, GDP dan jumlah penduduk negara pengimpor serta nilai tukar rupiah terhadap mata uang negara tersebut. Data kualitatif berupa kebijakan tarif dan non tarif yang berlaku di negara tujuan ekspor yang terkait dengan kebijakan SPS, TET dan persyaratan lain. Sumber data yang digunakan dalam penelitian ini berasal dari Instansi terkait antara lain Badan Pusat Statistik (BPS), Kementerian Kelautan dan Perikanan (KKP), Kementerian Pertanian (Kementan), Bank Indonesia (BI) dan beberapa situs penting lainnya yang berkaitan dengan penelitian ini yaitu Food Agricultural Organization (FAO), Globefish, Infofish, Eurostat, Japan Statistics, FDA USA.

Model persamaan dalam penelitian ini dianalisis dengan metode data panel (metode Generalized Least Squaref GLS) untuk menggambarkan selurub permintaan dan daya saing ekspor tuna ke tiga pasar tujuan (Uni Eropa, Amerika dan Jepang) dan metode Ordinary Least Square (OLS) untuk menggambarkan kondisi permintaan dan daya saing tuna di masing-masing pasar.

\section{Hipotesis I}

Untuk mengetahui pengaruh kebijakan tarif dan non-tarif terhadap permintaan tuna Indonesia di pasar Uni Eropa, Amerika dan Jepang maka permintaan tuna yang diproksi melalui volume ekspor tuna ke pasar tersebut diestimasi dengan persamaan regresi sebagai berikut

Tabel 2. Kebijakan Tarif Non-tarif di Uni Eropa, Amerika Serikat, dan Jepang

\begin{tabular}{|c|c|c|c|}
\hline \multirow{2}{*}{ Jenis Kebijakan } & Bentuk Kebijakan & \multirow{2}{*}{ Negara- } & \multirow{2}{*}{ Tahun Berlaku } \\
\hline & \multirow{3}{*}{$\begin{array}{l}\text { a. Generalized System of Preferences (GSP) } \\
\text { b. Penurunan Tarif pasca WTO }\end{array}$} & & \\
\hline & & Uni Eropa & $2002-2015$ \\
\hline & & Jepang & 1995-sekarang \\
\hline \multirow{4}{*}{$\begin{array}{l}\text { Non-Tarif: } \\
\text { a. Kebijakan Sanitary } \\
\text { and Phythosanitary } \\
\text { Measures (SPS) }\end{array}$} & & & \\
\hline & $\begin{array}{l}\text { a. Penerapan aturan baru Rapid Alert System } \\
\text { for Food and Feed (RASFF) }\end{array}$ & Uni Eropa & 2003-sekarang \\
\hline & $\begin{array}{l}\text { b. Penerapan Hazard Analytical Critical } \\
\text { Contral Point (HACCP) }\end{array}$ & Amerika & 1995-sekarang \\
\hline & c. Penerapan Food Safety Basic Law & Jepang & 2002-sekarang \\
\hline \multirow{3}{*}{$\begin{array}{l}\text { b. Kebijakan } \\
\text { Technical Barrier to } \\
\text { Trade (TBT) }\end{array}$} & a. Kebijakan Ecolabelling & Uni Eropa & 2001-sekarang \\
\hline & b. Kebijakan Country of Origin Label (COOL) & Amerika & 2005-sekarang \\
\hline & $\begin{array}{l}\text { c. Kebijakan Japan Agricultural Standard } \\
\text { (JAS) labelling }\end{array}$ & Jepang & 2001-sekarang \\
\hline \multirow{3}{*}{$\begin{array}{l}\text { c. Kebijakan selain } \\
\text { SPS dan } \\
\text { TBT }\end{array}$} & a. Pemberlakuan Systemic Border Conirol & Uni Eropa & $2006-2008$ \\
\hline & b. Kebijakan Dolphin Safe & Amerika & 1992-sekarang \\
\hline & c. Keharusan keanggotaan dalam Indian & Jepang & $1996-2008$ \\
\hline
\end{tabular}

Sumber: diolah dari berbagai sumber 


\section{a. Pasar Uni Eropa}

$$
\begin{aligned}
& \operatorname{In} Q_{x}-U E=\beta_{0}+\beta_{1} \operatorname{In} P_{x}+\beta_{2} \operatorname{In} P_{d}+\beta_{3} \\
& \operatorname{In} P_{w}+\beta_{4} \operatorname{In} P_{u}+\beta_{5} \operatorname{In} E_{r}+\beta_{6} \operatorname{In} P O P_{U E}+ \\
& \beta_{7} \operatorname{In} G D P_{U E}+\beta_{8} \operatorname{In} D_{1}+\beta_{9} \operatorname{In} D_{2}+\beta_{10} \\
& \operatorname{In} D_{3}+\beta_{11} \operatorname{In} D_{4}+e
\end{aligned}
$$

\begin{tabular}{|c|c|}
\hline QxUE & $\begin{array}{l}=\text { Volume ekspor tuna Indonesia ke Uni } \\
\text { Eropa (ton) }\end{array}$ \\
\hline$P_{x}$ & $\begin{aligned}= & \text { Harga ckspor tuna di Uni Eropa } \\
& \text { (US\$/ton) }\end{aligned}$ \\
\hline $\mathrm{d}$ & $=$ Harga tuna domestik $(\mathrm{Rp} / \mathrm{kg})$ \\
\hline $\mathrm{P}_{\mathrm{w}}$ & $=$ Harga tuna dunia (US\$/ton) \\
\hline $\mathrm{Pu}_{\mathrm{u}}$ & $=$ Harga ekspor udang (US\$/ton) \\
\hline $\mathrm{E}_{\mathrm{r}}$ & $\begin{aligned}= & \text { Nilai tukar rupiah terhadap mata uang } \\
& \text { negara pengimpor }(\mathrm{Rp} / \mathrm{US} \$)\end{aligned}$ \\
\hline OPUE & $=$ Jumlah penduduk di Uni Eropa (Jiwa) \\
\hline GDPUE & $=$ GDP di Uni Eropa (US\$) \\
\hline D1 & $\begin{array}{l}=1 \text { ketika diberlakukan SPS(RASFF), } \\
\mathrm{D}_{1}=0 \text { saat belum diberlakukan } \\
\text { pembaharuan RASFF }\end{array}$ \\
\hline $\mathrm{D}_{2}$ & $\begin{aligned}= & 1 \text { ketika diberlakukan TBT } \\
& \text { (Ecolabelling), } \mathrm{D}_{2}=0 \text { saat bclum } \\
& \text { diberlakukan Ecolabelling }\end{aligned}$ \\
\hline $\mathrm{D}_{3}$ & $\begin{array}{l}=1 \text { ketika diberlakukan Systemic Border } \\
\text { Control, } \mathrm{D} 3=0 \text { saat tidak } \\
\text { diberlakukan } \mathrm{SBC} .\end{array}$ \\
\hline D4 & $\begin{aligned}= & 1 \text { ketika diberlakukan Tarif (GSP), D4 } \\
& =0 \text { saat tidak diberlakukan GSP. }\end{aligned}$ \\
\hline & $=$ Konstanta \\
\hline & $=$ Parameter \\
\hline & $=$ Faktor kesalahan \\
\hline
\end{tabular}

\section{Keterangan:}

\section{b. Pasar Amerika Serikat}

$$
\begin{aligned}
& \operatorname{In} Q_{x}-U S A=\beta_{0}+\beta_{1} \operatorname{In} P_{x}+\beta_{2} \operatorname{In} P_{d}+\beta_{3} \\
& \operatorname{In} P_{w}+\beta_{4} \operatorname{In} P_{u}+\beta_{5} \operatorname{In} E_{r}+\beta_{6} \operatorname{In} P O P_{U S A} \\
& +\beta_{7} \operatorname{In} G D P_{U S A}+\beta_{8} \operatorname{In} D_{1}+\beta_{9} \operatorname{In} D_{2}+ \\
& \beta_{10} \operatorname{In} D_{3}+e
\end{aligned}
$$

Keterangan:

$$
\begin{aligned}
\text { QxUSA = } & \text { Volume ekspor tuna Indonesia ke } \\
& \text { Amerika Serikat (ton) } \\
\mathrm{Px}_{\mathrm{X}}= & \text { Harga ekspor tuna di Amerika } \\
& \text { Serikat (US\$/ton) } \\
\mathrm{Pd}= & \text { Harga tuna domestik }(\mathrm{Rp} / \mathrm{kg}) \\
\mathrm{Pu}_{\mathrm{W}}= & \text { Harga tuna dunia (US\$/ton) } \\
\mathrm{Pu}_{\mathrm{u}} & \text { Harga ekspor udang (US } \$ \text { ton) } \\
\mathrm{E}_{\mathrm{r}} & \text { Nilai tukar rupiah terhadap mata } \\
& \text { uang negara pengimpor }(\mathrm{Rp} / \mathrm{US} \$)
\end{aligned}
$$

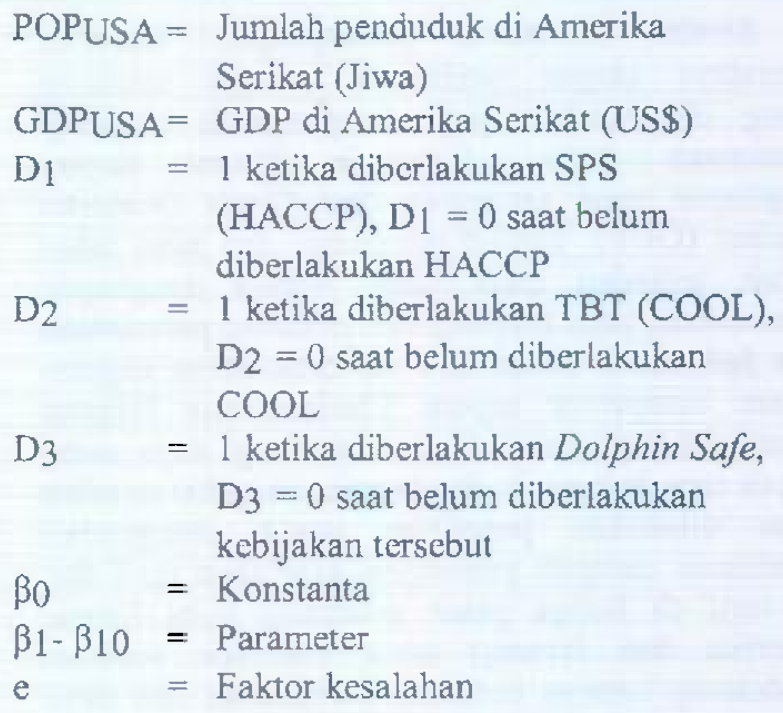

D3 = 1 ketika diberlakukan Dolphin Safe, D3 = 0 saat belum diberlakukan kebijakan tersebut

$\beta_{0}=$ Konstanta

$\beta_{1}-\beta_{10}=$ Parameter

e $\quad=$ Faktor kesalahan

\section{c. Pasar Jepang}

$$
\begin{aligned}
& \operatorname{In} Q_{x}-J P G=\beta_{0}+\beta_{1} \ln P_{x}+\beta_{2} \operatorname{In} P_{d}+\beta_{3} \\
& \ln P_{w}+\beta_{4} \ln P_{u}+\beta_{5} \ln E_{r}+\beta \\
& { }_{6} \text { InPOPUSA }_{\text {In }}+\beta_{7} \text { InGDPUSA }+ \\
& \beta_{8} \operatorname{In} D_{1}+\beta_{9} \operatorname{In} D_{2}+\beta_{10} \operatorname{In} D_{3} \\
& +\beta_{11} \operatorname{In} D_{4}+e
\end{aligned}
$$

Keterangan:

QxJPG = Volume ekspor tuna Indonesia ke Jepang (ton)

$\mathrm{P}_{\mathrm{X}} \quad=$ Harga ekspor tuna di Jepang (US\$/ton)

$\mathrm{Pd}_{\mathrm{d}} \quad=$ Harga tuna domestik $(\mathrm{Rp} / \mathrm{kg})$

$\mathrm{P}_{\mathrm{W}} \quad=$ Harga tuna dunia (US $\$ /$ ton)

$\mathrm{P}_{\mathrm{u}} \quad=$ Harga ekspor udang (US\$/ton)

$E_{\mathrm{T}} \quad=$ Nilai tukar rupiah terhadap mata uang negara pengimpor (Rp/US\$)

POPJPG $=$ Jumlah penduduk di Jepang (Jiwa)

GDPJPG = GDP di Jepang (US\$)

D1 = 1 ketika diberlakukan SPS(Food Safety Basic Law), D1 $=0$ saat bclum diberlakukan SPS

D2 $=1$ ketika dibcrlakukan TBT (Labelling), $\mathrm{D}_{2}=0$ saat belum diberlakukan TBT

D3 = 1 ketika diberlakukan Other Requirement (IOTC), D3 = 0 saat belum diberlakukan IOTC

D4 = 1 ketika diberlakukan Tarif (underWTO), D4 = 0 saat belum ada pengurangan tarif

$\beta_{0}=$ Konstanta

$\beta_{1}-\beta_{10}=$ Parameter

e $=$ Faktor kesalahan 


\section{Hipotesis II}

Untuk mengetahui pengaruh kebijakan tarif dan non-tarif terhadap daya saing ekspor tuna Indonesia maka daya saing ekspor tuna diestimasi dengan persamaan regresi sebagai berikut:

\section{a. Pasar Uni Eropa}

$$
\begin{aligned}
\operatorname{In} R C A_{\text {ue }}= & \beta_{0}+\beta_{1} \operatorname{In} Q_{d}+\beta_{2} \operatorname{In} M S+\beta_{3} \\
& \operatorname{InEr}+\beta_{4} \operatorname{In} P u+\beta_{5} \operatorname{In} P X_{\text {ind }}+\beta_{6} \\
& \operatorname{In} P X_{\text {thl }}+\beta_{7} \operatorname{In} P X_{p h l}+\beta_{8} \operatorname{In} D_{1} \\
& +\beta_{9} \operatorname{In} D_{2}+\beta_{10} \operatorname{In} D_{3}+\beta_{11} \operatorname{In} D_{4} \\
& +e
\end{aligned}
$$

Keterangan:

RCAUE $=$ Nilai indeks RCA Indonesia di Uni Eropa

Qd = Produksi tuna Indonesia (ton)

MS = Pangsa pasar tuna indonesia

ER = Nilai tukar Rupiah terhadap Euro ( $\mathrm{Rp} /$ Euro)

PU = Harga ekspor udang (Rp/ton)

PXIND = Harga ekspor tuna Indonesia (US\$/ton)

PXTHL = Harga ekspor tuna Thailand (US\$/ton)

PXPHL = Harga ekspor tuna Filipina (US\$/ton)

D1 = 1 ketika diberlakukan SPS(RASFF), $D_{1}=0$ saat belum diberlakukan pembaharuan RASFF

$\mathrm{D}_{2}=1$ ketika diberlakukan TBT (Ecolabelling), D2 = 0 saat belum diberlakukan Ecolabelling

D3 = 1 ketika diberlakukan Systemic Border Control, D3 $=0$ saat tidak diberlakukan SBC

D4 = 1 ketika diberlakukan Tarif (GSP), D4 = 0 saat tidak diberlakukan GSP

$\beta_{0}=$ Konstanta

$\beta 1-\beta 11=$ Parameter

e $=$ Faktor kesalahan

b. Pasar Amerika Serikat

$$
\begin{aligned}
\operatorname{In} R C A_{\text {usa }}= & \beta_{0}+\beta_{1} \operatorname{In} Q_{d}+\beta_{2} \operatorname{In} M S+\beta_{3} \\
& \operatorname{InEr}+\beta_{4} \operatorname{In} P u+\beta_{5} \operatorname{In} P X_{\text {ind }}+ \\
& \beta_{6} \operatorname{In} P X_{\text {thl }}+\beta_{7} \operatorname{In} P X_{p h l}+\beta_{8} \\
& \operatorname{In} D_{1}+\beta_{9} \operatorname{In} D_{2}+\beta_{10} \operatorname{In} D_{3}+e
\end{aligned}
$$

Keterangan:

RCAUSA $=$ Nilai indeks RCA tuna Indonesia di Amerika

Qd $\quad=$ Produksi tuna Indonesia (ton)
MS = Pangsa pasar tuna indonesia

ER = Nilai tukar Rupiah terhadap Euro (Rp/Euro)

PU $\quad=$ Harga ekspor udang (Rp/ton).

PXIND = Harga ekspor tuna Indonesia (US\$/ton)

PXTHL = Harga ekspor tuna Thailand (US\$/ton)

PXPHL = Harga ekspor tuna Philipina (US\$/ton)

D1 = 1 ketika dibcrlakukan SPS $(\mathrm{HACCP}), \mathrm{D}_{1}=0$ saat belum diberlakukan HACCP

D2 = 1 ketika diberlakukan TBT $(\mathrm{COOL}), \mathrm{D}_{2}=0$ saat belum diberlakukan COOL

D3 = 1 ketika diberlakukan Dolphin Safe, $\mathrm{D}_{3}=0$ saat belum diberlakukan kebijakan tersebut

$\beta_{0}=$ Konstanta

$\beta_{1}-\beta_{10}=$ Parameter

e = Faktor kesalahan

\section{c. Pasar Jepang}

$$
\begin{aligned}
\operatorname{InRCA} A_{j p g}= & \beta_{0}+\beta_{1} \operatorname{In} Q_{d}+\beta_{2} \operatorname{InMS}+\beta_{3} \\
& \operatorname{InEr}+\beta_{4} \operatorname{In} P u+\beta_{5} \operatorname{In} P X_{\text {ind }}+\beta \\
& { }_{6} \operatorname{In} P X_{t h l}+\beta_{7} \operatorname{In} P X_{p h l}+\beta_{8} \\
& \operatorname{In} D_{1}+\beta_{9} \operatorname{In} D_{2}+\beta_{10} \operatorname{In} D_{3}+ \\
& \beta_{1]} \operatorname{In} D_{4}+e
\end{aligned}
$$

Keterangan:

RCAJPG = Nilai indeks RCA tuna Indonesia di Jepang

Qd $\quad=$ Produksi tuna Indonesia (ton)

MS $\quad=$ Pangsa pasar tuna indonesia

ER = Nilai tukar Rupiah terhadap Yen (Rp/Ycn)

PU = Harga ekspor udang (Rp/ton)

PXIND = Harga ekspor tuna Indonesia (US\$/ton)

PXTHL = Harga ekspor tuna Thailand (US\$/ton)

PXPHL = Harga ekspor tuna Filipina (US\$/ton).

D1 = 1 ketika diberlakukan SPS(Food Safety Basic Law), D1 $=0$ saat belum diberlakukan SPS

D2 = 1 ketika diberlakukan TBT (Labelling), $\mathrm{D}_{2}=0$ saat belum diberlakukan TBT

D3 = 1 ketika diberlkaukan Other Requirement (IOTC), D3 $=0$ saat 
'Tabel 4. Analisis Regresi Faktor-faktor yang Mempengaruhi Permintaan Tuna Indonesia

\begin{tabular}{|c|c|c|c|c|c|}
\hline No & Variabel Independen & Umum & Uni Eropa & Amerika & Jepang \\
\hline 1 & Konstanta & $\begin{array}{l}-8.929 \\
(7,889)\end{array}$ & $\begin{array}{l}-156.142 \\
(32,169)\end{array}$ & $\begin{array}{l}-1211.603 \\
(283,578)\end{array}$ & $\begin{array}{l}-1224.219 \\
(206,917)\end{array}$ \\
\hline 2 & Harga Ekspor & $\begin{array}{l}0.110 \\
(0,199)\end{array}$ & $\begin{array}{l}0.058 \\
(0,071)\end{array}$ & $\begin{array}{l}-3.631^{* * *} \\
(0,498)\end{array}$ & $\begin{array}{l}-0.786^{* * *} \\
(0,294)\end{array}$ \\
\hline 3 & Harga Domestik & $\begin{array}{l}0.880^{* *} \\
(0,385)\end{array}$ & $\begin{array}{l}0.425 \\
(0,348)\end{array}$ & $\begin{array}{l}1.627^{* * *} \\
(0,475)\end{array}$ & $\begin{array}{l}-0.065 \\
(0,231)\end{array}$ \\
\hline 4 & Harga Dunia & $\begin{array}{l}1.826^{* * *} \\
(0,542)\end{array}$ & $\begin{array}{l}1.650^{* * * *} \\
(0,479)\end{array}$ & $\begin{array}{l}2.458^{* * *} \\
(0,743)\end{array}$ & $\begin{array}{l}0.718^{* *} \\
(0,286)\end{array}$ \\
\hline 5 & Harga Udang & $\begin{array}{l}0.395 \\
(0,509)\end{array}$ & $\begin{array}{l}-1.504^{* * *} \\
(0,370)\end{array}$ & $\begin{array}{l}4.742^{* * *} \\
(0,709)\end{array}$ & $\begin{array}{l}-0.471 \\
(0,324)\end{array}$ \\
\hline 6 & Nilai Tukar Rupiah & $\begin{array}{l}-2.564^{* * *} \\
(0,544)\end{array}$ & $\begin{array}{l}-1.258^{* * *} \\
(0,467)\end{array}$ & $\begin{array}{l}-5.226^{* * *} \\
(0,971)\end{array}$ & $\begin{array}{l}0.194 \\
(0,442)\end{array}$ \\
\hline 7 & Jumlah Penduduk & $\begin{array}{l}-2.310^{* * *} \\
(0,446)\end{array}$ & $\begin{array}{l}-3.353^{*} \\
(1,901)\end{array}$ & $\begin{array}{l}77.368^{* * *} \\
(20,170)\end{array}$ & $\begin{array}{l}65.955^{* * *} \\
(11,536)\end{array}$ \\
\hline 8 & Pendapatan Nasional & $\begin{array}{l}1.878^{* * *} \\
(0,461)\end{array}$ & $\begin{array}{l}7.944^{* * *} \\
(2,010)\end{array}$ & $\begin{array}{l}-9.725^{* *} \\
(3,844)\end{array}$ & $\begin{array}{l}0.335 \\
(0,352)\end{array}$ \\
\hline 9 & D1 (SPS) & $\begin{array}{l}-0.129 \\
(0,254)\end{array}$ & $\begin{array}{l}0.088 \\
(0,201)\end{array}$ & $\begin{array}{l}-1.816^{* * *} \\
(0,345)\end{array}$ & $\begin{array}{l}-0.484^{* * *} \\
(0,168)\end{array}$ \\
\hline 10 & $\mathrm{D} 2$ (TBT) & $\begin{array}{l}-0.856^{* *} \\
(0,343)\end{array}$ & $\begin{array}{l}-1.009^{* * *} \\
(0,218)\end{array}$ & $\begin{array}{l}-0.479 \\
(0,330)\end{array}$ & $\begin{array}{l}-0.167 \\
(0,183)\end{array}$ \\
\hline 11 & D3 (Lainnya) & $\begin{array}{l}-0.272 \\
(0,228)\end{array}$ & $\begin{array}{l}-0.585^{* * *} \\
(0,445)\end{array}$ & $\begin{array}{l}-0.925^{* * *} \\
(0,282)\end{array}$ & $\begin{array}{l}-0.242 \\
(0,206)\end{array}$ \\
\hline 12 & D4 (Tarif) & $\begin{array}{l}0.410^{*} \\
(0,244)\end{array}$ & $\begin{array}{l}0.481 \\
(0,336)\end{array}$ & $-\cdots$ & $\begin{array}{l}-0.282^{* *} \\
(0,162)\end{array}$ \\
\hline \multicolumn{2}{|c|}{$\begin{array}{l}\text { Adjusted } \mathrm{R}^{2} \\
\text { F-stat }\end{array}$} & 0,7046 & 0,8520 & 0,8671 & 0,8865 \\
\hline \multicolumn{6}{|c|}{$\begin{array}{l}\text { Sumber: Analisi data Sekunder, } 2010 \\
\text { Keterangan: }\end{array}$} \\
\hline \multicolumn{6}{|c|}{ * = Signifikan dengan tingkat kepercayaan $90 \%$} \\
\hline \multirow[t]{2}{*}{$* *$} & \multicolumn{5}{|c|}{$=$ Signifikan dengan tingkat kepercayaan $95 \%$} \\
\hline & $=$ Signifikan dengan tin & percayaan $99 \%$ & & & \\
\hline
\end{tabular}

Harga ekspor udang di pasar Uni Eropa dan Amerika signifikan dan bernilai negatif terhadap daya saing tuna. Koefisicn harga udang bertanda negatif menunjukkan bahwa udang dan tuna bukan sebagai barang subtitusi artinya kenaikan atau penurunan harga udang justru memberikan dampak sebaliknya pada daya saing tuna Indonesia. Sementara itu harga ekspor tuna Thailand sebagai salah satu pesaing tuna Indonesia berpengaruh signifikan di pasar Uni Eropa dan Jepang sedangkan harga ekspor Filipina berpengaruh signifikan di pasar Amerika. Harga ekspor perikanan Indonesia termasuk tuna secara umum cukup bersaing dibanding negara pengekspor lainnya seperti Thailand dan Filipina. Namun hal ini lebih disebabkan karena pengaruh nilai tukar yang cenderung undervalued dan stabil dibandingkan pengekspor lainnya.

Berdasarkan hasil uji t dalam analisis regresi data panel, tidak satupun kebijakan tarif yang berpengaruh signifikan terhadap daya saing ckspor tuna ke pasar produktif. Telah discbutkan sebelumnya bahwa pangsa pasar Indonesia di pasar Uni Eropa mulai berkurang. Menurunnya pangsa pasar tcrscbut juga disebabkan karena faktor non harga yang berupa regulasi baik berupa teknis maupun kemanan pangan. Berdasarkan hasil regresi regulasi SPS dan TBT tidak berpengaruh signifikan terhadap daya saing. Hal ini dikarenakan kedua pcraturan tersebut sudah lama diterapkan bagi para eksportir perikanan sehingga dapat diikuti sesuai dengan standar yang diterapkan. Namun peraturan lainnya yaitu penerapan systemic border control vang hanya dikenakan bagi Indonesia sejak 
tahun 2006 berpengaruh negatif terhadap daya saing sebesar $0,393 \%$. Peraturan ini menuntut eksportir Indonesia mengeluarkan biaya tambahan bagi pengujian logam berat dan histamine schingga membuat harga ekspor tuna menjadi lebih mahal. Penerapan HACCP berpengaruh signifikan terhadap daya saing sebesar $0,192 \%$. Pengaruh yang positif menunjukkan penerapan HACCP dapat diikuti oleh para eksportir Indonesia. Sedangkan kebijakan yang terkait dengan lingkungan seperti masalah by catch atau hasil tangkapan sampingan berpengaruh negatif terhadap daya saing sebesar $0,333 \%$. Sosialisasi penggunaan label bahwa tuna asal Indonesia ditangkap tanpa membunuh populasi lumba- lumba belum serentak dilakukan hal ini disebabkan masih mahalnya ongkos untuk menerapkannya. Sementara itu kebijakan SPS dan $\mathrm{TB}_{i}^{-}$berpengaruh positif terhadap indeks daya saing RCA Indonesia di pasar Jepang sebesar $0,198 \%$ dan $0,235 \%$. Kebijakan keanggotaan IOTC berpengaruh negatif terhadap daya saing sebesar $0,216 \%$.

Tabel 5. Analisis Regresi Faktor-faktor yang Mempengarubi Daya Saing Tuna Indonesia

\begin{tabular}{|c|c|c|c|c|c|}
\hline No & Variabel Independen & Umum & Uni Eropa & Amerika & Jepang \\
\hline 1 & Konstanta & $\begin{array}{r}5,527 \\
(0,889)\end{array}$ & $\begin{array}{r}8,744 \\
(1,468)\end{array}$ & $\begin{array}{r}6,459 \\
(0,334)\end{array}$ & $\begin{array}{c}2,633 \\
(0,714)\end{array}$ \\
\hline 2 & Produksi & $\begin{array}{r}-0,132^{* * *} \\
(0,038)\end{array}$ & $\begin{array}{r}-0,271^{* * *} \\
(0,100)\end{array}$ & $\begin{array}{r}-0,140^{* * *} \\
(0,020)\end{array}$ & $\begin{array}{c}-0,124^{* * *} \\
(0,024)\end{array}$ \\
\hline 3 & Pangsa Pasar & $\begin{array}{l}0,786^{* * *} \\
(0,051)\end{array}$ & $\begin{array}{c}1,254^{\text {******}} \\
(0,211)\end{array}$ & $\begin{array}{c}0,925^{* * * *} \\
(0,020)\end{array}$ & $\begin{array}{c}0,891^{\text {**** }} \\
(0,084)\end{array}$ \\
\hline 4 & Nilai Tukar & $\begin{array}{r}-0,105 \\
(0,204)\end{array}$ & $\begin{array}{r}0,035 \\
(0,390)\end{array}$ & $\begin{array}{r}-0,075 \\
(0,093)\end{array}$ & $\begin{array}{c}-0,298^{* *} \\
(0,146)\end{array}$ \\
\hline 5 & Harga Udang & $\begin{array}{r}-0,460^{* *} \\
(0,198)\end{array}$ & $\begin{array}{c}-0,386^{*} \\
(0,200)\end{array}$ & $\begin{array}{r}-0,398^{* * *} \\
(0,077)\end{array}$ & $\begin{array}{c}-0,055 \\
(0,119)\end{array}$ \\
\hline 6 & PX tuna Indonesia & $\begin{array}{c}0,947^{* * * *} \\
(0,081)\end{array}$ & $\begin{array}{c}0,996^{* * *} \\
(0,072)\end{array}$ & $\begin{array}{r}0,619^{* * *} \\
(0,069)\end{array}$ & $\begin{array}{c}0,297^{* * *} \\
(0,083)\end{array}$ \\
\hline 7 & PX tuna Thailand & $\begin{array}{r}-0,819^{* * *} \\
(0,301)\end{array}$ & $\begin{array}{c}-0,681^{*} \\
(0,360)\end{array}$ & $\begin{array}{r}-0,014 \\
(0,148)\end{array}$ & $\begin{array}{l}0,562^{* *} \\
(0,217)\end{array}$ \\
\hline 8 & PX tuna Philipina & $\begin{array}{r}0,338 \\
(0,342)\end{array}$ & $\begin{array}{r}0,025 \\
(0,415)\end{array}$ & $\begin{array}{r}-0,251^{* *} \\
(0,115)\end{array}$ & $\begin{array}{c}-0,382 \\
(0,241)\end{array}$ \\
\hline 9 & D1 (SPS) & $\begin{array}{r}0,212^{* *} \\
(0,104)\end{array}$ & $\begin{array}{r}-0,172 \\
(0,188)\end{array}$ & $\begin{array}{c}0,192^{* * * *} \\
(0,040)\end{array}$ & $\begin{array}{c}0,198^{* * *} \\
(0,062)\end{array}$ \\
\hline 10 & D2 (TBT) & $\begin{array}{r}-0,068 \\
(0,132)\end{array}$ & $\begin{array}{r}0,285 \\
(0,197)\end{array}$ & $\begin{array}{r}0,035 \\
(0,043)\end{array}$ & $\begin{array}{c}0,235^{* * *} \\
(0,072)\end{array}$ \\
\hline 11 & D3 (Lainnya) & $\begin{array}{r}0,039 \\
(0,093)\end{array}$ & $\begin{array}{r}-0,393^{* * *} \\
(0,113)\end{array}$ & $\begin{array}{r}-0,333^{* * *} \\
(0,030)\end{array}$ & $\begin{array}{l}-0,216^{* *} \\
(0,082)\end{array}$ \\
\hline 12 & D4(Tarif) & $\begin{array}{r}-0,229^{* *} \\
(0,098)\end{array}$ & $\begin{array}{r}-0,093 \\
(0,177)\end{array}$ & $\ldots$ & $\begin{array}{c}-0,024 \\
(0,059)\end{array}$ \\
\hline \multicolumn{2}{|c|}{ Adjusted $\mathrm{R}^{2}$} & 0,947 & 0,890 & 0,995 & 0,878 \\
\hline \multicolumn{2}{|c|}{$F$-stat } & 125,675 & 57,463 & 1428,802 & 51,488 \\
\hline
\end{tabular}

Sumber: Analisis Data Sekunder, 2010

Keterangan:

- Signifikan dengan tingkat kepercayaan $90 \%$

* Signifikan dengan tingkat kepercayaan $95 \%$

*** = Signifikan dengan tingkat kepercayaan $99 \%=$ Standar eror

D1 (SPS) = Dummy Kebijakan tentang Sanitary and PhytosanitaryMeasures

D2 (TBT) = Dummy kebijakan tentang Technical Barriers to Trade

D3 (Lainnya) $=$ Dummy kebijakan selain SPS dan TBT

D4 (Tarif) = Dummy Kebijakan Tarif 


\section{Kebijakan Tarif}

Salah satu tujuan dalam penelitian ini adalah menganalisis dampak penerapan kebijakan tarif yang ada di negara tujuan ekspor. Penelitian tentang kebijakan terscbut difokuskan untuk Uni Eropa dan Jepang sedangkan kebijakan tarif di Amerika tidak dilakukan karena tingkat tarif yang berlaku sudah sangat kecil bahkan mencapai nol persen untuk beberapa kategori produk tuna. Salah satu kebijakan tarif yang dilakukan oleh Uni Eropa bagi Indonesia khususnya untuk produk perikanan adalah pemberlakuan General System Preferences (GSP) berupa pengenaan tingkat tarif tertentu dibawah tarif normal untuk scjunlah kuota yang telah ditetapkan. Pengurangan tarif juga berlaku di Jepang terutama sejak perubahan General Agreement on Tariff and Trade (GATT) menjadi World Trade Organization (WTO) pada tahun 1994 dimana semua negara sepakat untuk mengurangi hambatan perdagangan berupa tarif secara bertahap hingga mencapai nol persen. Tarif tuna segar atau beku semula berkisar $10 \%-5 \%$ dalam perjanjian GATT diturunkan menjadi $3,5 \%$ dan tarif tuna kaleng semula 20\% - 15\% (GATT) menjadi 9,6\% dan sudah diturunkan lebih rendah lagi hingga $6,4 \%$ bahkan nol persen dalam perundingan tertentu.

\section{Kebijakan Non-tarif}

Secara teori, pendirian food safety standards (baik SPS maupun TBT) dapat memfasilitasi perdagangan melalui pengurangan biaya transaksi, dengan meyakinkan konsumen bahwa produk yang dikonsumsi telah memenuhi standar yang berlaku dan mengurangi kerugian dalam menaksir kualitas produk. Bagi eksportir, dengan memenuhi standar tersebut maka dapat mengurangi resiko penolakan produk oleh importir. Standar tersebut dapat digunakan sebagai jaminan untuk menilai kualitas produk di pasar dan meningkatkan elastisitas subtitusi diantara produk yang sama antar negara yang berbeda sehingga produsen yang lebih efisicnlah yang dapat menguasai pasar (Athukorala dan Jayasuriya (2005) cit., Sykes (1995), Kindleberger (1985)).

Namun dalam prakteknya, penerapan food safety standards tersebut dapat menghalangi perdagangan karena beberapa alasan. Pertama, penerapan peraturan tersebut dirasakan semakin kompleks dan sulit untuk dipenuhi. Hal ini karena mahalnya biaya untuk memenuhinya dibebankan kepada eksportir. Standar yang ada sekarang ini dirancang sedemikian rupa sebagai pencerminan kemajuan teknologi maju dan perubahan selera konsumen di negara importir yang mungkin belum sesuai bagi negara eksportir yang teknologinya masih sederhana. Kedua, penerapan standar tersebut tidak transparan dalam pembuktian secara ilmiah (scientific justification). Ketiga, frekuensi perubahannya yang demikian cepat sehingga menghalangi negara berkembang seperti Indonesia menjadi pemain yang efektif dalam mengimplementasikan peraturan tersebut. Akibatnya timbul anggapan bahwa peraturan tersebut lebih digunakan sebagai alat proteksi terselubung oleh negara maju ketimbang sebagai alat untuk melindungi kesehatan manusia, hewan dan tumbuhan.

\section{Sanitary and Phytosanitary Measures (SPS Measures)}

Ketiga negara maju yang menjadi pasar ekspor utama dunia yaitu Uni Eropa, Amerika Serikat dan Jepang memiliki cara masing-masing untuk menguji produk perikanan tersebut. Uni Eropa melalui sistem RASFF, Amerika dengan HACCP dan Jepang dengan Food Safety Basic Law yang semakin ketat disamping Food Sanitation and Quarantine Law yang telah diterapkan sebelumnya. Berdasarkan analisis regresi, kebijakan non-tarif yang terkait dengan aspck SPS Measures di ketiga negara importir berpengaruh signifikan terhadap ekspor tuna Indonesia.

Jika dibandingkan jumlah border cases relatif terhadap jumlah impor (per 100.000 ton) di ketiga negara importir maka Amerika memiliki nilai perbandingan yang paling tinggi diantara kedua negara importir lainnya. Hal ini berbeda dengan Uni Eropa yang menggunakan pendekatan prevention at source sehingga dapat menekan kasus penolakan yang terjadi di negara pengekspor. Telah dijelaskan sebelumnya bahwa Uni Eropa menempatkan Competent Authority (CA) di masing-masing negara mitra dagangnya untuk menjamin kesesuaian standar sebelum produk dikirim. Dengan demikian beberapa kasus akibat ketidaksesuaian standar dapat terdeteksi di negara pengekspor. Pendekatan ini tcrbukti lebih preventif dan lebih efektif dari segi biaya daripada hanya mengandalkan kontrol pada pelabuhan masuk. Seperti halnya Jepang, telah melakukan upaya serupa dengan menempatkan SDMnya di negara eksportir sehingga dapat menjamin kesesuaian dengan standar yang berlaku di negara tersebut.

\section{Technical Barrier to Trade (TBT)}

Jika dibandingkan dengan SPS maka penolakan produk perikanan karena alasan TBT jauh lebih sedikit sebagaimana yang ditunjukkan 
dari hasil analisis regresi. Kebijakan TBT hanya berpengaruh pada ekspor Indonesia ke Uni Eropa sedangkan ke Amerika dan Jepang tidak berpengaruh signifikan. Hal ini mungkin disebabkan karena peraturan tentang penggunaan label masih bersifat sukarela (compulsory) di kedua negara tersebut. Berbeda dengan Uni Eropa, kesadaran konsumen yang terus meningkat tentang kualitas pangan, keschatan dan lingkungan yang berkesinambungan berpengaruh penting terhadap perkembangan standar labeling yang diterapkan oleh UE. Negara tersebut telah merevisi standar labellingnya dan mulai tahun 2001 peraturan ini bersifat wajib (mandatory requirement).

Hasil analisis regresi menunjukkan bahwa penggunaan label membawa dampak positif bagi ekspor tuna Indonesia ke Uni Eropa yaitu setiap $1 \%$ peningkatan peraturan penggunaan label di negara tersebut meningkatkan ekspor tuna Indonesia sebesar $0,808 \%$. Hal ini dikarenakan penggunaan label berkaitan dengan citra produk perikanan sebagaimana yang diungkapkan oleh Valentini (2005). Perkembangan penggunaan label pada produk ekspor perikanan didasarkan pada dua hal. Pertama, perkembangan permintaan akan produk yang aman bagi lingkungan. Konsumen di UE lebih menyenangi produk atau barang yang diproduksi dengan teknik yang ramah lingkungan (ecological label/ eco-labelling). Konsumen mau membayar dengan harga yang lebih mahal untuk produk tersebut dan lebih memilih membeli green product ketimbang brown product walaupun secara fisik memiliki karakteristik yang sama. Kedua, kebutuhan informasi produk antara penjual dan pembeli.

\section{Persyaratan Lainnya (Selain SPS dan TBT)}

Negara-negara berkembang sebagai eksportir produk perikanan saat ini sedang dihadapkan pada masalah baru tentang peraturan lain yang berhubungan dengan standar keamanan lingkungan. Negara yang sangat memperhatikan masalah lingkungan adalah Amerika dan Jepang sedangkan Uni Eropa lebih fokus kepada masalah food safety.

Masalah lingkungan yang diberlakukan oleh Amerika berkaitan dengan perikanan antara lain by catch (dolphin issue). Berdasarkan hasil analisis regresi, dampak pengenaan kebijakan tersebut berpengaruh signifikan terhadap ekspor tuna Indonesia. Setiap $1 \%$ pengetatan peraturan tersebut dapat meningkatkan ekspor tuna Indonesia sebesar $1,4887 \%$. Hal ini karena kebijakan tersebut lebih difokuskan kepada negara-negara yang melakukan kegiatan penangkapan tuna di wilayah samudera pasifik sebelah timur (Eastern Tropical
Pacifik/ETP). Sedangkan bagi nelayan Indonesia sangat sedikit yang melakukan kegiatan penangkapannya di wilayah tersebut sehingga tidak berpengaruh besar terhadap ekspor tuna.

Sementara itu isu lingkungan yang diterapkan oleh Jepang berupa kewajiban negara pantai (coastal state) untuk bergabung dalam keanggotaan RFMO di Samudera Hindia (Indian Ocean Tuna Commision/IOTC. Pada tahun 2002 ckspor perikanan Indonesia ternasuk tuna diembargo oleh Jepang karena belum bergabungnya Indonesia dalam organisasi tersebut. Kerugian lain yang ditimbulkan adalah hasil tangkapan tuna dari Indonesia yang diekspor ke negara tersebut dihargai 50 yen per kilogram lebih rendah dibandingkan dengan negara lain yang telah masuk menjadi anggota IOTC. Hal ini sejalan dengan hasil analisis regresi yang menunjukkan pengaruh negatif terhadap ekspor perikanan Indonesia akibat diterapkannya kebijakan tersebut.

Keanggotaan Indonesia dalam Regional Fisheries Management Organization (RFMO) baik di Samudera Hindia maupun di Samudera Pasifik merupakan keharusan. Dengan diterimanya Indonesia menjadi anggota IOTC pada 2007 sebagai anggota ke-27 membuat posisi Indonesia mulai diperhitungkan sebagai salah satu negara produsen tuna terbesar di dunia serta dalam perundingan di beberapa forum tuna dunia (Solikhin, 2006).

Masuknya Indonesia sebagai anggota RFMO tersebut memberi dampak positif bagi kenyamanan berusaha terutama dalam penangkapan tuna di laut lepas (high seas). Selain itu, sebagai anggota dari IOTC Indonesia tidak lagi dianggap melakukan penangkapan tuna secara illegal di perairan laut lepas kawasan Samudera Hindia serta mendapatkan jaminan akses pemasaran tuna di pasar Internasional. Indonesia juga dapat turut menentukan kuota hasil tangkapan maupun kuota ekspor. Hal ini berarti pengembangan usaha perikanan tangkap khususnya tuna tidak lagi bergantung terhadap kuota yang diberikan negara lain.

Sclain berdampak positif bagi pengusaha, keikutsertaan Indonesia di berbagai RFMO tersebut membuat posisi Indonesia di liga tuna dunia juga semakin kuat. Pemerintah Indonesia mempunyai hak suara untuk memberikan pendapat dan usulan terkait pemanfaatan tuna dunia. Manfaat lain yang tidak kalah penting adalah Indonesia juga dapat menghemat waktu dan biaya yang sangat mahal karena adanya kesempatan kerjasama penelitian dan pengumpulan data perikanan, pemanfaatan Total Allowable Catch (TAC), Monitoring Controlling and Surveillance (MCS) 
dan penegakan hukum serta pengelolaan dan konservasi sumberdaya ikan yang banyak membutuhkan tenaga ahli.

\section{KESIMPULAN}

1. Permintaan tuna Indonesia di pasar produktif secara umum dipengaruhi oleh harga domestik, harga dunia, nilai tukar rupiah, jumlah penduduk, pendapatan nasional, kebijakan non-tarif berupa penerapan TBT serta kebijakan tarif.

2. Daya saing tuna Indonesia di pasar produktif secara umum dipengaruhi oleh produksi, pangsa pasar, harga udang, harga ekspor tuna Indonesia, harga ekspor tuna Thailand, kebijakan non-tarif yang berupa SPS dan kebijakan tarif.

3. Kebijakan tarif semakin tidak berpengaruh terhadap permintaan dan daya saing tuna Indonesia ke pasar produktif. Sementara itu kebijakan non-tarif (SPS dan TBT) di Uni Eropa memegang peranan penting bagi pengembangan ekspor tuna ke pasar produktif. Pendekatan prevention at source dengan menerapkan Competent Authority (CA) di masing-masing negara eksportir yang dilakukan olch Uni Eropa terbukti efektif schingga meminimalisir kasus penolakan produk perikanan ke negara terscbut.

4. Harga ekspor di Uni Eropa dan harga udang di Jepang merupakan penentu utama bagi peningkatan permintaan tuna Indonesia di pasar produktif.

5. Impor perikanan Jepang akan produk tuna dari Indonesia yang sudah rutin dilakukan dan besarnya pangsa pasar tuna Indonesia di Jepang menyebabkan perubahan pendapatan nasional (GDP Jepang) tidak mempengaruhi permintaan tuna Indonesia ke negara tersebut.

\section{DAFTAR PUSTAKA}

Ahmed, M. 2006. Market Access and Trade Liberalisation in Fisheries. ICTSD Natural Resources. Issue Paper No.4. International Centre for Trade and Sustainable Development.Geneva, Switzeriand.

Athukorala dan Jayasuriya. Food Safety Issue, Trade and WTO Rules: Developing Country Perspective.

Departemen Kelautan dan Perikanan. 2006. Peluang Pasar Produk Tuna. Gema Mina. Vol. IV No.2 Direktorat Jendral Perikanan Tangkap. DKP. Jakarta .1983-2009. Statistik Ekspor. Hasil Perikanan 1983-2009. Direktorat Jendral Pcrikanan Budidaya. DKP. Jakarta.

FAO. 2007. Future Prospects for Fish and Fisheries Products; Fish Consumption in the European Union in 2015 and 2030. Part I: European Overview. FAO Fisheries Circular. No.972/4.

Gujarati. D. 1999. Ekonometri Dasar. Frlangga. Jakarta.

Kocswoyo, T. 2007. Dampak Kebijakan Non-tarif terhadap Permintaan Ekspor Udang ke Uni Eropa. Tesis. UGM. Jogjakarta. (tidak dipublikasikan).

Solihin, A. Perikanan Indonesia dalam Kepungan Organisasi Pengelolaan Perikanan Regional dan Internasional. Diakses tanggal 16 Januari 2010.

Valentini, L. 2005. Environtmental Quality Provision and Eco-Labelling: Some Issue. WTO Economics Research and Statistics Division. 